\title{
Job satisfaction of ISSEMyM medical staff during the sanitary contingency due to severe acute respiratory syndrome coronavirus 2
}

\author{
Claudia Jiménez-Vargas ${ }^{1}$, Carolina E. López-Dorado², and Mónica D. Martín-de Saro ${ }^{*}$ \\ ${ }^{1}$ External Consultation Service; ${ }^{2}$ Department of Psychology; ${ }^{3}$ Research Service, Maternal and Child Hospital, Social Security Institute of the State \\ of Mexico and Municipalities (ISSEMyM). Toluca, State of Mexico, Mexico
}

\begin{abstract}
Satisfaction is known to be a relevant issue in the workplace, because of productivity, job rotation, and loss of working hours, reflecting emotional and attitudinal components capable of showing how work activity is linked to both cognitive and affective domains of the worker. Most of the research studies on job satisfaction carried out in Mexico focus on the nursing staff, reflecting little interest in the medical community and other health professionals (nutritionists, psychologists, and physical rehabilitation) that make up the community within a $3^{\text {rd }}$ level hospital. The purpose of this study was to know the job satisfaction in the medical staff of ISSEMYM Maternal and Child Hospital through the S20/23 questionnaire during the COVID-19 health contingency, to determine areas for improvement and generate strategies that will be reflected in positive attitudes of the professional of health, which will ultimately have an impact on the quality of care for the beneficiary and hospital productivity. The results obtained show $83 \%$ personal job satisfaction (intrinsic), however, supervision and benefits showed satisfaction in only $59 \%$ and $51 \%$, respectively. Therefore, strategies should be aimed at improving participation, management style, and non-tangible incentives.
\end{abstract}

Key words: Job satisfaction. Medical stuff. ISSEMyM. Intrinsic satisfaction. Extrinsic satisfaction. Severe acute respiratory syndrome coronavirus 2.

\section{Introduction}

Job satisfaction is a construct with three elements contained in its definition. First, job satisfaction as an emotional state involving an affective component. Second, job satisfaction and experiences different from other satisfactions and third, there is a cognitive or evaluative component ${ }^{1}$."

The evaluation of job satisfaction has gained special relevance for all organizations, including health organizations not only because of its association with adherence to the organization, job rotation, and loss of work hours but also in terms of productivity and quality ${ }^{2}$.
Employees with a high level of involvement at work identify with the kind of work they do and really care and are associated with lower absenteeism and resignation rates ${ }^{3}$. This is why the directors of the institutions must be able to attract, motivate, reward, retain, train, and satisfy their staff so that they provide a quality service that satisfies the client, showing kindness and good spirit.

Any medical organization must serve the interests of service providers, since inattention to the satisfaction of the individual's needs structure and motivators easily translates into burnout syndrome. Burnout is the result

\section{Correspondence:}

*Mónica D. Martín-de Saro

E-mail: mdms190783@yahoo.com.mx

0185-1063/O 2021 Sociedad Médica del H NC-ND license (http://creativecommons.org/licenses/by-nc-nd/4.0/).
Date of reception: $26-04-2021$

Date of acceptance: $20-07-2021$

DOI: 10.24875/HGMX.21000034
Available online: 18-10-2021

Rev Med Hosp Gen Mex. 2021;84(4):154-162 www.hospitalgeneral.mx 
of a process in which the worker is exposed to a situation of chronic work stress (at least 6 continuous months) and in which the coping strategies used are not effective. The symptoms of burnout can be classified according to the committed sphere, psychiatric: progressive and covert deterioration of the person, such as chronic depression and anxiety, character disorders, suicide, serious family dysfunctions (violence), and addictions (including work addiction). Somatic: Table of stress with varied expressions of muscular, endocrine, nervous, circulatory, and other psychosomatic types. Organizational: Deterioration in labor relations that cause different types of effects, such as the impoverishment of professional development, rivalry, individualism, repeated operational failures, demotivation, and non-conformity 4 . Therefore, it can be concluded that job satisfaction is related to job productivity and performance, as well as to situations that are not favorable for the employee such as stress, burnout syndrome, absenteeism, and turnover ${ }^{5}$.

In March 2020 in Mexico, the red traffic light was established, which began the contingency phase due to the severe acute respiratory syndrome coronavirus 2 (SARS-CoV-2) virus, bringing not only a new disease (COVID-19) but also uncertainty, stress, emotional, and physical fatigue and sometimes unfortunately mourning in the medical staff. The foregoing could affect job satisfaction since the high risk of infection, inadequate personal protective equipment, absence of security conditions or unfavorable hiring working conditions, lack of biosanitary or therapeutic supplies, isolation, exhaustion, long hours, and lack of family contact are factors that contribute to a greater presence of symptoms of stress or anxiety, feelings of panic, depression, and anguish in doctors who work in the midst of epidemics. Lifestyle changes as a result of the epidemic have sometimes been associated with greater emotional disturbance in health professionals, therefore, they must make cognitive and behavioral efforts as coping responses to stressful situations ${ }^{6}$.

A study of medical personnel in Iran at the beginning of the SARS-CoV-2 pandemic found in a sample of 304 health professionals that $28 \%$ suffered from anxiety, $30.6 \%$ depression, and $20.1 \%$ stress. It is mentioned that job satisfaction was also decreased but it is not mentioned which tool they used for the measurement ${ }^{\text {. }}$ Previous research studies related to job satisfaction carried out in Mexico, are led mainly by the Mexican Institute of Social Security (IMSS) focused only on nursing personnel ${ }^{8}$. As a direct consequence, a limited frame of reference is generated for the planning, implementation, and monitoring of strategies that allow motivating and increasing the sense of belonging in doctors and health professionals toward their institutions.

Due to the aforementioned, it was essential to know the job satisfaction in health personnel within the outpatient area of the ISSEMyM Maternal and Child Hospital in times of a COVID-19 pandemic, to determine areas for improvement, which allow generating strategies that have an impact on the quality of care for the beneficiary and in hospital productivity.

\section{Material and Methods}

A descriptive, cross-sectional study was carried out using the Meliá and Peiró measuring instrument S20/23 to the 64 members of the health staff who provided outpatient consultation in May 2020 at the ISSEMyM Maternal and Child Hospital. The questionnaire consisted of a section with demographic variables such as gender, age, marital status, degree of studies, occupation, working hours, and service in which they carry out their activities and employment situation; and another section with the 23 items of the five study factors, with the five ratings from 1 to 5 for each item. The instrument was given to each of the health professionals who provided outpatient consultation, during their work shift with the recommended health measures. The objective of the study was fully explained to each participant and since the staff did not know the instrument, it was explained in detail how to answer it. A period of $48 \mathrm{~h}$ was given to be answered. After $48 \mathrm{~h}$, each of the questionnaires was collected personally. The Research Ethics Committee of the unit with number 01-2020 approved this work.

The S20/23 version is an instrument that consists of 23 items and can be considered the most structurally complete reduced version of those developed from Meliá and Pieró's S4/82. The General Questionnaire of Satisfaction in Labor Organizations (S4/82) is a measure of 82 items with seven alternatives each (From "1. Very Dissatisfied" to "7. Very Satisfied"). Unfortunately, the investment of time due to the length of the questionnaire and the motivational costs due to the exhaustiveness of the content are especially important, consequently, the S20/23 instrument was developed, which presents an alpha of 0.92 and the factors range between 0.76 and 0.89 .22 . This was designed to obtain a useful and rich evaluation of content of job satisfaction taking into account, the motivational and temporal restrictions to which subjects are frequently exposed in 
organizational contexts and excluded the items for which the answer "Indifferent" is too common. The selection of the items of the questionnaire S2/84, to carry out $\mathrm{S} 20 / 23$, it was carried out through a complex interactive multicriteria process where a solution was sought. In conjunction with the following selective criteria:

1. Relevant content items from two points of view:

(a) due to the importance of the stated aspect and

(b) due to its level of general relevance across roles and organizations, which implies, from an empirical point of view, minimizing the number of subjects who respond "indifferent" to an item.

2. Items that maximize criteria validity. The validity coefficients of the items referring to the following external criteria were simultaneously managed: (a) tension associated with the role; (b) role conflict; (c) role ambiguity; and (d) propensity to drop out. In addition to maintaining a strong relationship with the total of the $S 4 / 82$.

3. Items that maintained the reliability of the questionnaire located at 0.95 for the 82 -item version.

4. Items that allow a factorial structure that is theoretically consistent and coherent with that of S4/82.

The selections of the 23 items presented relevant content for practically any organizational role in any organization ${ }^{7}$. Within the variables of interest, the five factors measured by the S20/23 questionnaire were taken into account, these are:

- Factor I satisfaction with supervision, relative to the way superiors judge the task. It was evaluated with reagents number $13,14,15,16,17$, and 18 of the instrument.

- Factor II satisfaction with the physical environment, relative to the physical environment and the space in the place. Work, cleanliness, hygiene, and health. It was evaluated with the reagents $6,7,8,9$, and 10 of the instrument.

- Factor III satisfaction with the benefits received, referring to the degree to which the company complies with the agreement, the way in which the negotiation occurs, the salary received, the opportunities for promotion and training. It was evaluated with reagents $4,11,12,22$, and 23 of the instrument.

- Factor IV intrinsic job satisfaction refers to the satisfactions that work itself gives the opportunities that work offers to do what they like or in which they excel, the objectives and goals. It was evaluated with reagents 1, 2, 3, and 5 .

- Factor V satisfaction with participation refers to satisfaction with participation in the decisions of the
Table 1. General characteristics of the surveyed medical personnel

\begin{tabular}{|c|c|c|}
\hline Variable & No. & $\%$ \\
\hline $\begin{array}{l}\text { Gender } \\
\text { Female } \\
\text { Male }\end{array}$ & $\begin{array}{l}23 \\
28\end{array}$ & $\begin{array}{l}45.1 \\
54.9\end{array}$ \\
\hline $\begin{array}{l}\text { Age } \\
20-29 \\
30-39 \\
40-49 \\
50-59 \\
60-69\end{array}$ & $\begin{array}{c}4 \\
8 \\
20 \\
18 \\
1\end{array}$ & $\begin{array}{c}7.8 \\
16 \\
39.2 \\
35.2 \\
1.9\end{array}$ \\
\hline $\begin{array}{l}\text { Marital status } \\
\text { Married } \\
\text { Single } \\
\text { Free union }\end{array}$ & $\begin{array}{c}32 \\
15 \\
4\end{array}$ & $\begin{array}{c}62.8 \\
29.4 \\
7.8\end{array}$ \\
\hline $\begin{array}{l}\text { Study grade } \\
\text { Bachelor's degree } \\
\text { Master's degree } \\
\text { Doctorate } \\
\text { Other }\end{array}$ & $\begin{array}{l}24 \\
16 \\
3 \\
8\end{array}$ & $\begin{array}{c}47.0 \\
31.3 \\
5.9 \\
15.6\end{array}$ \\
\hline $\begin{array}{l}\text { Medical area } \\
\text { Gynecology and obstetrics } \\
\text { Pediatrics } \\
\text { Surgery }\end{array}$ & $\begin{array}{l}11 \\
27 \\
13\end{array}$ & $\begin{array}{l}21.3 \\
52.9 \\
25.4\end{array}$ \\
\hline $\begin{array}{l}\text { Schedule } \\
\text { Morning } \\
\text { Evening } \\
\text { Special } \\
\text { Mixed }\end{array}$ & $\begin{array}{c}38 \\
10 \\
2 \\
1\end{array}$ & $\begin{array}{l}74.5 \\
19.6 \\
3.9 \\
1.9\end{array}$ \\
\hline $\begin{array}{l}\text { Employment situation } \\
\text { Base } \\
\text { Alternate }\end{array}$ & $\begin{array}{c}44 \\
7\end{array}$ & $\begin{array}{l}86.3 \\
13.7\end{array}$ \\
\hline
\end{tabular}

work group, the department or section, or the task itself. It was evaluated with reagents 19,20 , and $21^{9}$. The data obtained from each of the previously qualified questionnaires were emptied into a spreadsheet of the Microsoft Excel program, placing a consecutive number on each of the questionnaires, maintaining the anonymity of the participants by emptying their responses according to each of the questions in the questionnaire, and placing the response number from 1 to 5 . Where number 5 corresponded to very satisfied, number 4 to satisfied, number 3 to indifferent, number 2 to dissatisfied, and finally number 1 to very dissatisfied. Responses 4 and 5 were taken into account to rate the questionnaires with satisfaction and responses 3,2 , and 1 for all questionnaires with dissatisfaction. Finally, percentages were made according to the number of people who were satisfied and those who were not. Inferential statistics were performed using the SPSS versus 23 program to determine if there were 
Table 2. Satisfaction with the work supervision of the surveyed medical personnel

\begin{tabular}{|c|c|c|c|c|}
\hline \multicolumn{5}{|c|}{ Supervision } \\
\hline Variable & Dissatisfied & Indeterminate & Satisfied & $\mathbf{p}$ \\
\hline $\begin{array}{l}\text { Age } \\
20-29 \\
30-39 \\
40-49 \\
50-59 \\
60-69\end{array}$ & $\begin{array}{l}1 \\
2 \\
5\end{array}$ & $\begin{array}{l}2 \\
3 \\
5\end{array}$ & $\begin{array}{c}4 \\
5 \\
15 \\
8 \\
1\end{array}$ & 0.44 \\
\hline $\begin{array}{l}\text { Gender } \\
\text { Female } \\
\text { Male }\end{array}$ & $\begin{array}{l}2 \\
5\end{array}$ & $\begin{array}{l}5 \\
2\end{array}$ & $\begin{array}{l}16 \\
21\end{array}$ & 0.25 \\
\hline $\begin{array}{l}\text { Marital status } \\
\text { Single } \\
\text { Married } \\
\text { Free union }\end{array}$ & $\begin{array}{l}2 \\
4\end{array}$ & $\begin{array}{l}1 \\
8 \\
1\end{array}$ & $\begin{array}{c}12 \\
20 \\
3\end{array}$ & 0.77 \\
\hline $\begin{array}{l}\text { Academic degree } \\
\text { Bachelor's degree } \\
\text { Master degree } \\
\text { Doctorate } \\
\text { Others }\end{array}$ & $\begin{array}{l}3 \\
2 \\
1\end{array}$ & $\begin{array}{l}4 \\
2 \\
2 \\
1\end{array}$ & $\begin{array}{c}17 \\
12 \\
1 \\
6\end{array}$ & 0.17 \\
\hline $\begin{array}{l}\text { Employment situation } \\
\text { Base } \\
\text { Alternate }\end{array}$ & $\begin{array}{l}6 \\
1\end{array}$ & $\begin{array}{l}8 \\
1\end{array}$ & $\begin{array}{c}30 \\
5\end{array}$ & 0.99 \\
\hline $\begin{array}{l}\text { Working day } \\
\text { Morning } \\
\text { Evening } \\
\text { Special } \\
\text { Mixed }\end{array}$ & $\begin{array}{l}5 \\
- \\
1 \\
1\end{array}$ & $\begin{array}{l}8 \\
1 \\
- \\
-\end{array}$ & $\begin{array}{c}25 \\
9 \\
1 \\
-\end{array}$ & 0.10 \\
\hline $\begin{array}{l}\text { Area } \\
\text { Surgery } \\
\text { Pediatrics } \\
\text { Gynecology and obstetrics }\end{array}$ & $\begin{array}{l}1 \\
4 \\
3\end{array}$ & $\begin{array}{l}4 \\
3 \\
1\end{array}$ & $\begin{array}{c}8 \\
20 \\
7\end{array}$ & 0.36 \\
\hline
\end{tabular}

statistically significant differences between the age groups, shifts, marital status, and degree of studies, among others, considering as significant $p<0.05$.

\section{Results}

A total of 64 S20/23 instruments were delivered to the workforce of the outpatient clinic every shift at the ISSEMyM Maternal and Child Hospital. Thirteen surveys $(20 \%)$ were eliminated, since the staff did not agree to collaborate with this research work. It is worth mentioning that the work shift that least agreed to participate was the special shift (Saturdays, Sundays, and holidays); where, out of six people who work that shift, only two people agreed to carry out the survey (33\%).

The average age of the 51 participants was 44 years with a range of 24 and 60 years, respectively. The service that conducted the most surveys was the pediatric service with 27 surveys, which represented $52.9 \%$ (Fig. 1). Male gender predominated among those surveyed with 28 participants. Due to the fact that the highest number of consultations is granted in the morning shift, the shift with the highest participation was this with a total of 38 surveys conducted, which represented $74.5 \%$ (Table 1).

The majority of health personnel who provided outpatient consultation at the time of the survey were married (32 participants, 63\%). The most frequent academic degree was bachelor's degree in $47 \%$.

And finally, $86 \%$ of the surveyed health personnel (44 participants) were base doctors, and the remaining $14 \%$ (11 participants) were substitute doctors, this because the surveys were carried out in times of health contingency due to the SARS virus-CoV-2 and some basic physicians were in home care (Table 1). 


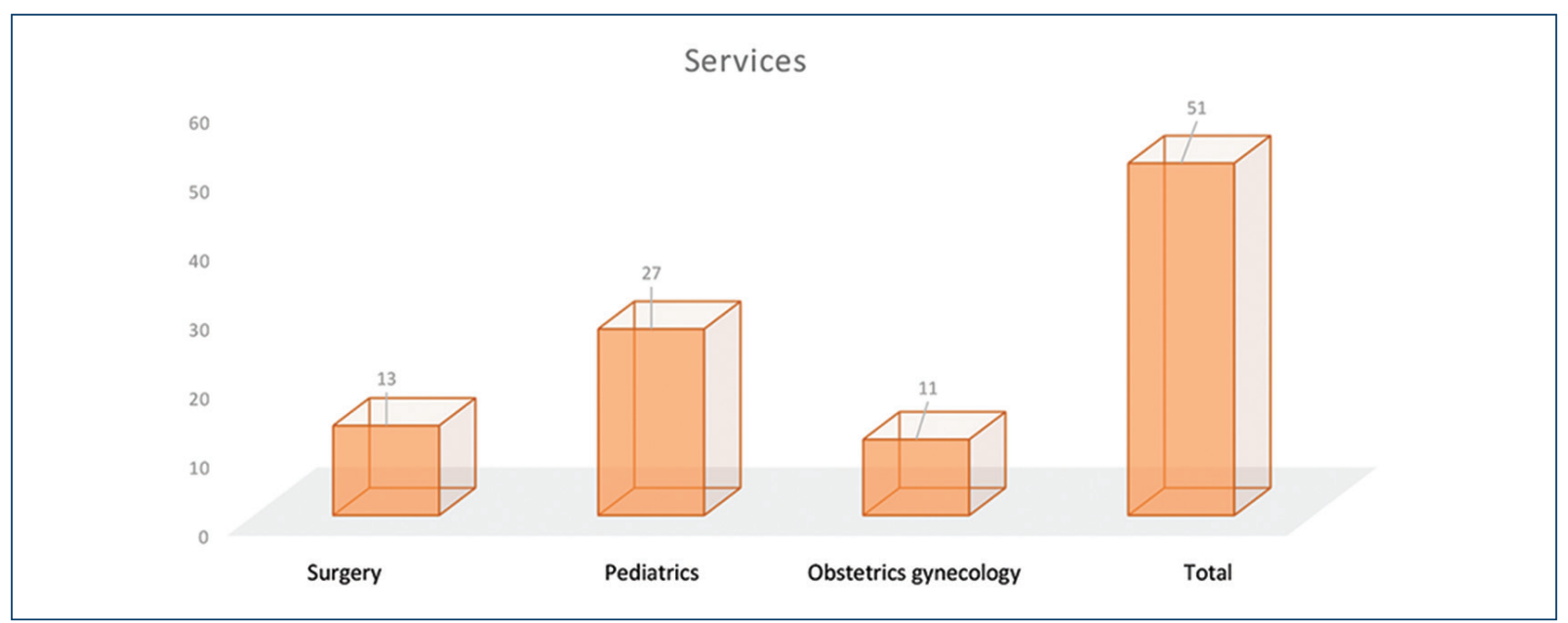

Figure 1. Number of participants surveyed by service.

Table 3. Satisfaction with the physical work environment

\begin{tabular}{|c|c|c|c|c|}
\hline \multicolumn{5}{|c|}{ Physical environment } \\
\hline Variable & Dissatisfied & Indeterminate & Satisfied & $\mathbf{p}$ \\
\hline $\begin{array}{l}\text { Edad (year) } \\
20-29 \\
30-39 \\
40-49 \\
50-59 \\
60-69\end{array}$ & 5 & $\begin{array}{l}1 \\
2 \\
6 \\
5\end{array}$ & $\begin{array}{c}3 \\
6 \\
14 \\
8 \\
1\end{array}$ & 0.22 \\
\hline $\begin{array}{l}\text { Gender } \\
\text { Female } \\
\text { Male }\end{array}$ & $\begin{array}{l}2 \\
4\end{array}$ & $\begin{array}{l}2 \\
6\end{array}$ & $\begin{array}{l}19 \\
18\end{array}$ & 0.51 \\
\hline $\begin{array}{l}\text { Marital status } \\
\text { Single } \\
\text { Married } \\
\text { Free union }\end{array}$ & $\begin{array}{l}1 \\
5\end{array}$ & $\begin{array}{c}4 \\
11 \\
1\end{array}$ & $\begin{array}{c}10 \\
16 \\
3\end{array}$ & 0.82 \\
\hline $\begin{array}{l}\text { Academic degree } \\
\text { Bachelor's degree } \\
\text { Master's degree } \\
\text { Doctorate } \\
\text { Others }\end{array}$ & $\begin{array}{l}2 \\
2 \\
1\end{array}$ & $\begin{array}{l}2 \\
4 \\
1 \\
4\end{array}$ & $\begin{array}{c}20 \\
10 \\
1 \\
4\end{array}$ & 0.28 \\
\hline $\begin{array}{l}\text { Employment situation } \\
\text { Base } \\
\text { Alternate }\end{array}$ & 5 & $\begin{array}{l}8 \\
1\end{array}$ & $\begin{array}{c}31 \\
6\end{array}$ & 0.55 \\
\hline $\begin{array}{l}\text { Working day } \\
\text { Morning } \\
\text { Evening } \\
\text { Special } \\
\text { Mixed }\end{array}$ & 5 & $\begin{array}{l}8 \\
1\end{array}$ & $\begin{array}{c}25 \\
9 \\
2 \\
1\end{array}$ & 0.81 \\
\hline $\begin{array}{l}\text { Area } \\
\text { Surgery } \\
\text { Pediatrics } \\
\text { Gynecology and obstetrics }\end{array}$ & $\begin{array}{l}1 \\
4\end{array}$ & $\begin{array}{l}1 \\
5 \\
3\end{array}$ & $\begin{array}{c}11 \\
18 \\
8\end{array}$ & 0.30 \\
\hline
\end{tabular}




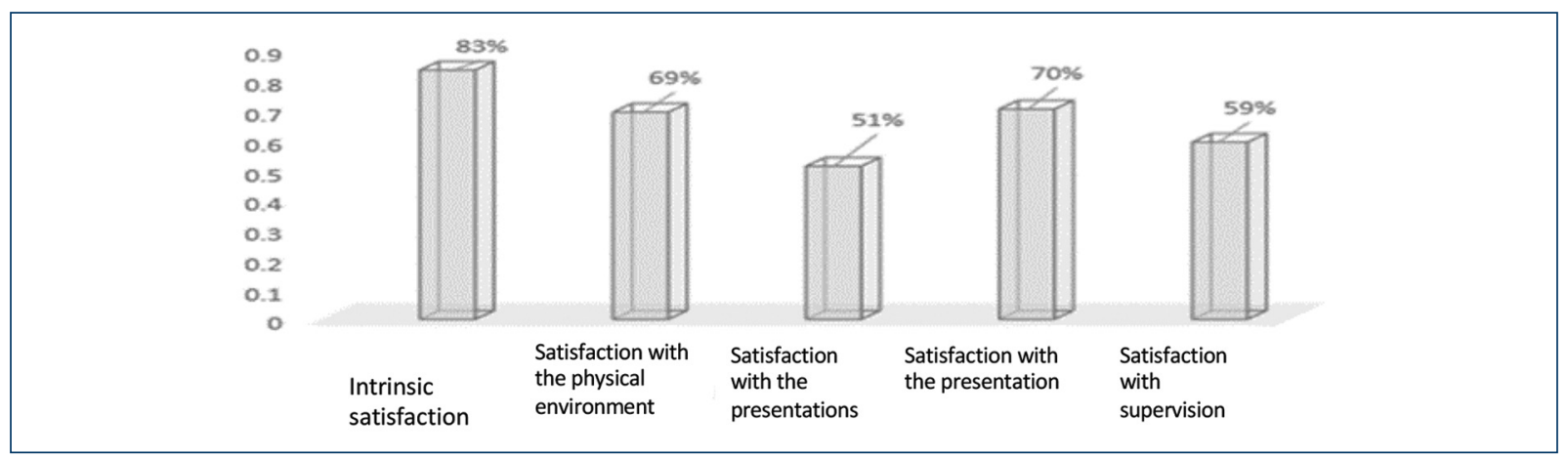

Figure 2. Degree of job satisfaction in the 5 areas.

Table 4. Satisfaction with labor participation

\begin{tabular}{|c|c|c|c|c|}
\hline \multicolumn{5}{|c|}{ Participation } \\
\hline Variable & Dissatisfied & Indeterminate & Satisfied & $\mathbf{p}$ \\
\hline $\begin{array}{l}\text { Age } \\
20-29 \\
30-39 \\
40-49 \\
50-59 \\
60-69\end{array}$ & $\begin{array}{l}- \\
1 \\
2 \\
3 \\
-\end{array}$ & $\begin{array}{l}1 \\
1 \\
4 \\
5 \\
-\end{array}$ & $\begin{array}{c}3 \\
6 \\
14 \\
10 \\
1\end{array}$ & 0.96 \\
\hline $\begin{array}{l}\text { Gender } \\
\text { Female } \\
\text { Male }\end{array}$ & $\begin{array}{l}2 \\
4\end{array}$ & $\begin{array}{l}8 \\
3\end{array}$ & $\begin{array}{l}13 \\
21\end{array}$ & 0.11 \\
\hline $\begin{array}{l}\text { Marital status } \\
\text { Single } \\
\text { Married } \\
\text { Free union }\end{array}$ & $\begin{array}{l}- \\
5 \\
1\end{array}$ & $\begin{array}{l}5 \\
6 \\
-\end{array}$ & $\begin{array}{c}10 \\
21 \\
3\end{array}$ & 0.31 \\
\hline $\begin{array}{l}\text { Academic degree } \\
\text { Bachelor's degree } \\
\text { Master's degree } \\
\text { Doctorate } \\
\text { Others }\end{array}$ & $\begin{array}{l}2 \\
1 \\
1 \\
2\end{array}$ & $\begin{array}{l}7 \\
3 \\
1 \\
1\end{array}$ & $\begin{array}{c}15 \\
12 \\
1 \\
5\end{array}$ & 0.55 \\
\hline $\begin{array}{l}\text { Employment situation } \\
\text { Base } \\
\text { Alternate }\end{array}$ & $\begin{array}{l}6 \\
-\end{array}$ & $\begin{array}{l}9 \\
2\end{array}$ & $\begin{array}{c}29 \\
5\end{array}$ & 0.56 \\
\hline $\begin{array}{l}\text { Working day } \\
\text { Morning } \\
\text { Evening } \\
\text { Special } \\
\text { Mixed }\end{array}$ & $\begin{array}{l}5 \\
- \\
1 \\
-\end{array}$ & $\begin{array}{l}8 \\
2 \\
- \\
1\end{array}$ & $\begin{array}{c}25 \\
8 \\
1\end{array}$ & 0.22 \\
\hline $\begin{array}{l}\text { Area } \\
\text { Surgery } \\
\text { Pediatrics } \\
\text { Gynecology and obstetrics }\end{array}$ & $\begin{array}{l}1 \\
4 \\
1\end{array}$ & $\begin{array}{l}5 \\
3 \\
2\end{array}$ & $\begin{array}{c}7 \\
20 \\
8\end{array}$ & 0.51 \\
\hline
\end{tabular}

At a general level, the staff maintained an intrinsic satisfaction of $83 \%$ (43 participants),

This factor being the highest of the 5 . The satisfaction factor with the benefits was the lowest where only 26 of the participants $(51 \%)$ were satisfied. The lowest item in the entire survey was salary, with $69 \%$ of participants considering that salary is low (Fig. 2). 
Table 5. Intrinsic job satisfaction

\begin{tabular}{|c|c|c|c|c|}
\hline \multicolumn{5}{|c|}{ Intrinsic satisfaction } \\
\hline Variable & Dissatisfied & Indeterminate & Satisfied & $\mathbf{p}$ \\
\hline $\begin{array}{l}\text { Edad } \\
20-29 \\
30-39 \\
40-49 \\
50-59 \\
60-69\end{array}$ & 1 & $\begin{array}{l}1 \\
1 \\
3\end{array}$ & $\begin{array}{c}4 \\
7 \\
19 \\
14 \\
1\end{array}$ & 0.60 \\
\hline $\begin{array}{l}\text { Gender } \\
\text { Female } \\
\text { Male }\end{array}$ & 1 & $\begin{array}{l}3 \\
2\end{array}$ & $\begin{array}{l}20 \\
25\end{array}$ & 0.65 \\
\hline $\begin{array}{l}\text { Marital status } \\
\text { Single } \\
\text { Married } \\
\text { Free union }\end{array}$ & 1 & 5 & $\begin{array}{c}15 \\
26 \\
4\end{array}$ & 0.51 \\
\hline $\begin{array}{l}\text { Academic degree } \\
\text { Bachelor's degree } \\
\text { Master's degree } \\
\text { Doctorate } \\
\text { Others }\end{array}$ & 1 & $\begin{array}{l}1 \\
3 \\
1\end{array}$ & $\begin{array}{c}22 \\
13 \\
3 \\
7\end{array}$ & 0.87 \\
\hline $\begin{array}{l}\text { Employment situation } \\
\text { Base } \\
\text { Alternate }\end{array}$ & 1 & $\begin{array}{l}4 \\
1\end{array}$ & $\begin{array}{c}39 \\
6\end{array}$ & 0.73 \\
\hline $\begin{array}{l}\text { Working } \\
\text { Morning } \\
\text { Evening } \\
\text { Special } \\
\text { Mixed }\end{array}$ & 1 & $\begin{array}{l}4 \\
1\end{array}$ & $\begin{array}{c}33 \\
10 \\
1 \\
1\end{array}$ & 0.40 \\
\hline $\begin{array}{l}\text { Area } \\
\text { Surgery } \\
\text { Pediatrics } \\
\text { Gynecology and obstetrics }\end{array}$ & 1 & $\begin{array}{l}6 \\
2\end{array}$ & $\begin{array}{c}13 \\
20 \\
9\end{array}$ & 0.64 \\
\hline
\end{tabular}

The satisfaction factor with the physical environment obtained $69 \%$, this due to the greater number of consultations that are granted in the morning shift, which is why, sometimes, it is necessary to share an office and there are physical spaces that have had to be adapted to offer medical assistance.

Statistically significant differences were sought between the different satisfaction factors of the instrument by age group, gender, marital status, academic degree, employment status, hours, and work area, without finding statistically significant differences between all groups (Tables 2-6).

\section{Discussion}

Despite the fact that the study was carried out in a period of time with peculiar characteristics, such as the health contingency caused by the SARS-CoV-2 virus, the health personnel of the external consultation who worked and agreed to carry out the survey presented $83 \%$ satisfaction in factor IV or intrinsic satisfaction which indicated that health personnel were emotionally satisfied just for doing their job, even in times of a pandemic. This situation was favorable for the medical unit, for patient care and in general for the ISSEMyM, assuming emotional intelligence and resilience in the health personnel working in the outpatient clinic.

Research studies have shown that employees who are clearly intrinsically motivated in relation to their work perform better than those who are extrinsically motivated; in addition, they have greater job satisfaction and a more positive attitude toward their organization ${ }^{10}$. In this research work, the substitute staff showed greater job satisfaction, as in the Colombian research work in the medical staff of the outpatient clinic, this derived from the fact that the performance is stronger among new 
Table 6. Satisfaction with job benefits

\begin{tabular}{|c|c|c|c|c|}
\hline \multicolumn{5}{|c|}{ Benefits } \\
\hline Variable & Dissatisfied & Indeterminate & Satisfied & $\mathbf{p}$ \\
\hline $\begin{array}{l}\text { Age } \\
20-29 \\
30-39 \\
40-49 \\
50-59 \\
60-69\end{array}$ & $\begin{array}{l}3 \\
1 \\
5\end{array}$ & $\begin{array}{l}3 \\
1 \\
8 \\
7\end{array}$ & $\begin{array}{c}1 \\
4 \\
11 \\
6 \\
1\end{array}$ & 0.09 \\
\hline $\begin{array}{l}\text { Gender } \\
\text { Female } \\
\text { Male }\end{array}$ & $\begin{array}{l}5 \\
5\end{array}$ & $\begin{array}{c}10 \\
8\end{array}$ & $\begin{array}{c}8 \\
15\end{array}$ & 0.35 \\
\hline $\begin{array}{l}\text { Marital status } \\
\text { Single } \\
\text { Married } \\
\text { Free unión }\end{array}$ & $\begin{array}{l}2 \\
5\end{array}$ & $\begin{array}{c}7 \\
14 \\
1\end{array}$ & $\begin{array}{c}6 \\
13 \\
3\end{array}$ & 0.91 \\
\hline $\begin{array}{l}\text { Academic degree } \\
\text { Bachelor's degree } \\
\text { Master's degree } \\
\text { Doctorate } \\
\text { Others }\end{array}$ & $\begin{array}{l}4 \\
3 \\
2\end{array}$ & $\begin{array}{l}10 \\
6 \\
3 \\
2\end{array}$ & $\begin{array}{c}10 \\
7 \\
4\end{array}$ & 0.87 \\
\hline $\begin{array}{l}\text { Employment situation } \\
\text { Base } \\
\text { Alternate }\end{array}$ & $\begin{array}{l}7 \\
2\end{array}$ & $\begin{array}{c}16 \\
4\end{array}$ & $\begin{array}{c}21 \\
1\end{array}$ & 0.23 \\
\hline $\begin{array}{l}\text { Working day } \\
\text { Morning } \\
\text { Evening } \\
\text { Special } \\
\text { Mixed }\end{array}$ & $\begin{array}{l}6 \\
1 \\
1\end{array}$ & $\begin{array}{c}16 \\
5\end{array}$ & $\begin{array}{c}16 \\
5 \\
1\end{array}$ & 0.16 \\
\hline $\begin{array}{l}\text { Area } \\
\text { Surgery } \\
\text { Pediatrics } \\
\text { Gynecology and obstetrics }\end{array}$ & $\begin{array}{l}1 \\
4 \\
3\end{array}$ & $\begin{array}{c}7 \\
12 \\
2\end{array}$ & $\begin{array}{c}5 \\
11 \\
6\end{array}$ & 0.09 \\
\hline
\end{tabular}

employees, and considerably more weak for the more experienced ${ }^{3}$.

Satisfaction with benefits and especially with salary was low, however, it does not seem to be an issue that affects the intrinsic satisfaction factor, and reiterates that monetary remuneration is not the only factor that motivates the worker, since to the extent where money becomes a standard factor at work, it immediately loses its motivational capacity ${ }^{11}$.

However, job satisfaction in general differs from that found in previous research studies such as the one carried out in Colombia, where the most satisfied outpatient personnel were young personnel. In this research study, it was shown that the personnel with the highest satisfaction in the intrinsic factor were found at the extremes of life, both in the personnel aged 2029 years and 60-69 years. An explanation for this would be that young people and older health personnel expect a lot from their work and consider that the rewards at work are close to their expectations ${ }^{12}$.

Another factor that affects the job satisfaction of Mexican doctors is multiemployment, low pay, and low non-tangible incentives such as professional promotions and lack of recognition ${ }^{2}$. This research study corroborates this statement since the satisfaction factors with the benefits and with the participation were low with $51 \%$ and $70 \%$. Unfortunately, this study did not investigate whether medical personnel had more than one job. The reason why the weekend and holiday shift had little participation in this study is unknown, but we know that it is usually the shift that least participates in various hospital activities.

\section{Conclusion}

1. This research work is the first to be carried out in this line of research, so far not used in the Social Security Institute of the State of Mexico and Municipalities, 
(ISSEMyM). Specifically in the Maternal and Child Hospital.

2. Demonstrates the importance of knowing the general job satisfaction of its workers to plan and apply strategies in the areas of improvement, as this study showed, where health personnel perceive dissatisfaction with the benefits, with supervision and with the participation.

3. It reveals and with evidence, already known situations, such as dissatisfaction with the benefits received; but that, despite this does not diminish the intrinsic satisfaction in the health personnel who provide outpatient consultation which infers the adherence of the personal to his profession, to this medical unit, and finally to the quality of care of the beneficiaries, which is excellent for the institute.

4. It makes evident the need to train tactical personnel in types of leadership, assertive communication, conflict resolution, derived from the fact that only $59 \%$ of the surveyed health personnel were satisfied with the supervision.

5. On the other hand, using more non-tangible incentives should be part of future strategies to increase factor III with respect to satisfaction with benefits and thus maintain factor IV of intrinsic satisfaction. Mainly in $14 \%$ of the surveyed personnel, who found themselves dissatisfied in the intrinsic satisfaction?

6. Finally reassessing the working staff after the application of the strategies will be decisive to demonstrate the effectiveness of these. Moreover, it will allow the realization of new research works.

\section{Acknowledgments}

To all medical personnel who voluntarily participated in the study.

\section{Funding}

No type of funding support was required to carry out this work.

\section{Conflicts of interest}

The authors declare that there are no conflicts of interest.

\section{Ethical disclosures}

Protection of human and animal subjects. The authors declare that no experiments were performed on humans or animals for this study.

Confidentiality of data. The authors declare that they have followed the protocols of their work center on the publication of patient data.

Right to privacy and informed consent. The authors declare that no patient data appear in this article.

\section{References}

1. Mason E. Gender differences in job Satisfaction. J Soc Psychol 1995;135:143-51.

2. Cruz R. Factores Asociados al Nivel de Satisfacción Laboral del Personal Médico III Suárez Angamos. Tesis de post-grado, Perú, Universidad Privada San Martín Porres; 2016. Available from: https://hdl.handle. net/20.500.12727/2583

3. Robbins S. Grados de Satisfaccion Laboral. México, Cd de México: Editorial Hispanoamericana; 2003.

4. López EA, Cano C, Salazar V. Caracterización del Síndrome de Burnout del Personal de Salud que Labora en Telemedicina, Durante la Pandemia COVID 19 [Disertación] Universidad Cooperativa de Colombia, Facultad de Ciencias Económicas, Administrativas y Contables; 2020.

5. Pérez $\mathrm{P}$, Azzollini S. Liderazgo, equipos y grupos de trabajo: Su relación con la satisfacción laboral. Rev Psicol. 2013;31:151-69.

6. Monterrosa A, Dávila R, Mejía A, Contreras J, Mercado M, Flores C. Estrés laboral, ansiedad y miedo al COVID-19 en médicos generales colombianos. MedUNAB. 2020;23:195-213.

7. Zhang SX, Liu J, Jahanshahi AA, Nawaser K, Yousefi A, et al. At the height of the storm: Healthcare staff's health conditions and job satisfaction and their associated predictors during the epidemic peak of $\mathrm{CO}$ VID-19. Brain Behav Immun. 2020;87:144-6.

8. Tapia H, Ramírez C, Islas E. Satisfacción laboral en enfermeras del hospital de oncología Centro Medico Nacional siglo XXI IMSS. Enferm Univ. 2009;6:21-5.

9. Meliá J, Peiró J. La medida de la satisfacción laboral en contextos organizacionales: El Cuestionario de Satisfacción S20/23. Psicologemas. 1989;5:59-74.

10. Ramírez R, Abreu J, Badii M. La motivación laboral, factor fundamental para el logro de objetivos organizacionales: Caso empresa manufacturera de tubería de acero. Daena. 2008;3:143-85.

11. Pinto J. El legado de Frederick Irving Herzberg. Rev Univ EAFIT. 2006;38:78-86.

12. Janson $P$, Martin J. Job satisfaction and age: a test of two views. Soc Forces. 1982;60:1089-102. 